\title{
Félix Vicq d'Azyr: Anatomy, Medicine and Revolution
}

\author{
André Parent
}

\begin{abstract}
Félix Vicq d'Azyr was born in 1748 in the small town of Valognes, Normandy. He studied medicine in Paris but he was particularly impressed by the lectures given at the Jardin du Roi by the comparative anatomist Louis Daubenton and the surgeon Antoine Petit. In 1773, Vicq d'Azyr initiated a series of successful lectures on human and animal anatomy at the Paris Medical School, from which he received his medical degree in 1774 . He was elected the same year at the Academy of Sciences at age 26, thanks to his outstanding contributions to comparative anatomy. Vicq d'Azyr became widely known after his successful management of a severe cattle plague that occurred in the southern part of France in 1774, an event that led to the foundation of the Royal Society of Medicine in 1778. As Permanent Secretary of this society, Vicq d'Azyr wrote several eulogies that were models of eloquence and erudition and worth him a seat at the French Academy in 1788. Vicq d'Azyr published in 1786 a remarkable anatomy and physiology treatise: a large in-folio that contained original descriptions illustrated by means of nature-sized, colored, human brain figures of a quality and exactitude never attained before. In 1789, Vicq d'Azyr was appointed physician to the Queen Marie-Antoinette and, in 1790, he presented to the Constituent Assembly a decisive plan to reform the teaching of medicine in France. Unfortunately, Vicq d'Azyr did not survive the turmoil of the French Revolution; he died at age 46 on June 20, 1794.
\end{abstract}

RÉSUMÉ: Felix Vicq d'Azyr : Anatomie, médecine et révolution. Félix Vicq d'Azyr naît en 1748 à Valognes en Normandie. Il étudie aux écoles de médecine de Paris, mais il est surtout impressionné par les leçons d'anatomie de Louis Daubenton et d'Antoine Petit au Jardin du Roi. En 1773, ses propres cours sur l'anatomie humaine et animale ont un succès retentissant. L'année suivante, à l'âge de 26 ans, il obtient son doctorat en médecine et est élu à l'Académie des sciences grâce à des travaux originaux sur l'anatomie des oiseaux et des poissons. Sa façon très efficace de gérer l'épizootie qui survient dans le sud-ouest de la France en 1774 lui vaut une reconnaissance nationale et conduit à la création de la Société Royale de Médecine en 1778. À titre de secrétaire perpétuel de cette société, Vicq d'Azyr prononce de nombreux éloges qui sont des modèles d'éloquence et d'érudition et qui le propulsent à l'Académie Française en 1788. Vicq d'Azyr publie en 1786 un traité d'anatomie et de physiologie remarquable, tant par la qualité de ses illustrations du cerveau humain que par la précision et l'originalité de ses descriptions anatomiques. In 1789, Vicq d'Azyr est nommé médecin auprès de la reine Marie-Antoinette et en 1790 il présente à l'Assemblée Nationale un plan "révolutionnaire" visant à réformer de fond en comble l'enseignement médical en France. Malheureusement, Vicq d'Azyr ne survivra pas à la tourmente révolutionnaire. Forcé de participer à la fête de l'Être suprême organisée par Robespierre le 8 juin 1794, il meurt 12 jours plus tard à 46 ans.

Can. J. Neurol. Sci. 2007; 34: 30-37

Félix Vicq d'Azyr (Figure 1) was born on April 23, 1748, in the small town of Valognes in Normandy, France. His father, Maître Jean-Félix Vicq, Sieur de Valemprey, a physician trained at Montpellier, was practicing medicine in Valognes. His family, including his mother Catherine Lechevalier, was rooted in French nobility since the 16th century, with an uninterrupted descent of physicians, municipal magistrates and public notaries. Vicq d'Azyr received his first education at the seminary of Valognes and then moved to Caen, where he studied philosophy and met a fellow student by the name of Pierre-Simon Laplace (1749-1792), who was to become a famous mathematician and astronomer. Vicq d'Azyr showed a real talent for literature and poetry in his early studies, but was convinced by his father to pursue the familial tradition of going into medicine; he thus moved to Paris in 1765 at age $17 . .^{1-4}$

Disappointed by the rather dull and static medical lessons provided by teachers at the Paris Medical School, then located on rue de la Bûcherie, he attended the much more inspired lectures given at the Jardin du Roi (or Jardin Royal des Plantes) on anatomy, physiology, chemistry, pharmacology and botany. What impressed him most were the lectures of the physician and surgeon Antoine Petit (1722-1794), who introduced him to human anatomy, and those of Louis-Jean-Marie Daubenton (1716-1799) (Figure 2A), who taught him the importance of

From the Centre de Recherche Université Laval Robert-Giffard, Beauport, Québec, Canada.

ReCEIVEd August 10, 2006. ACCEPTEd In FinAl Form OCtOBER 28, 2006 Reprint requests to: André Parent, Centre de Recherche Université Laval RobertGiffard, 2601, Chemin de la Canardière, Beauport, Québec, G1J 2G3, Canada. 


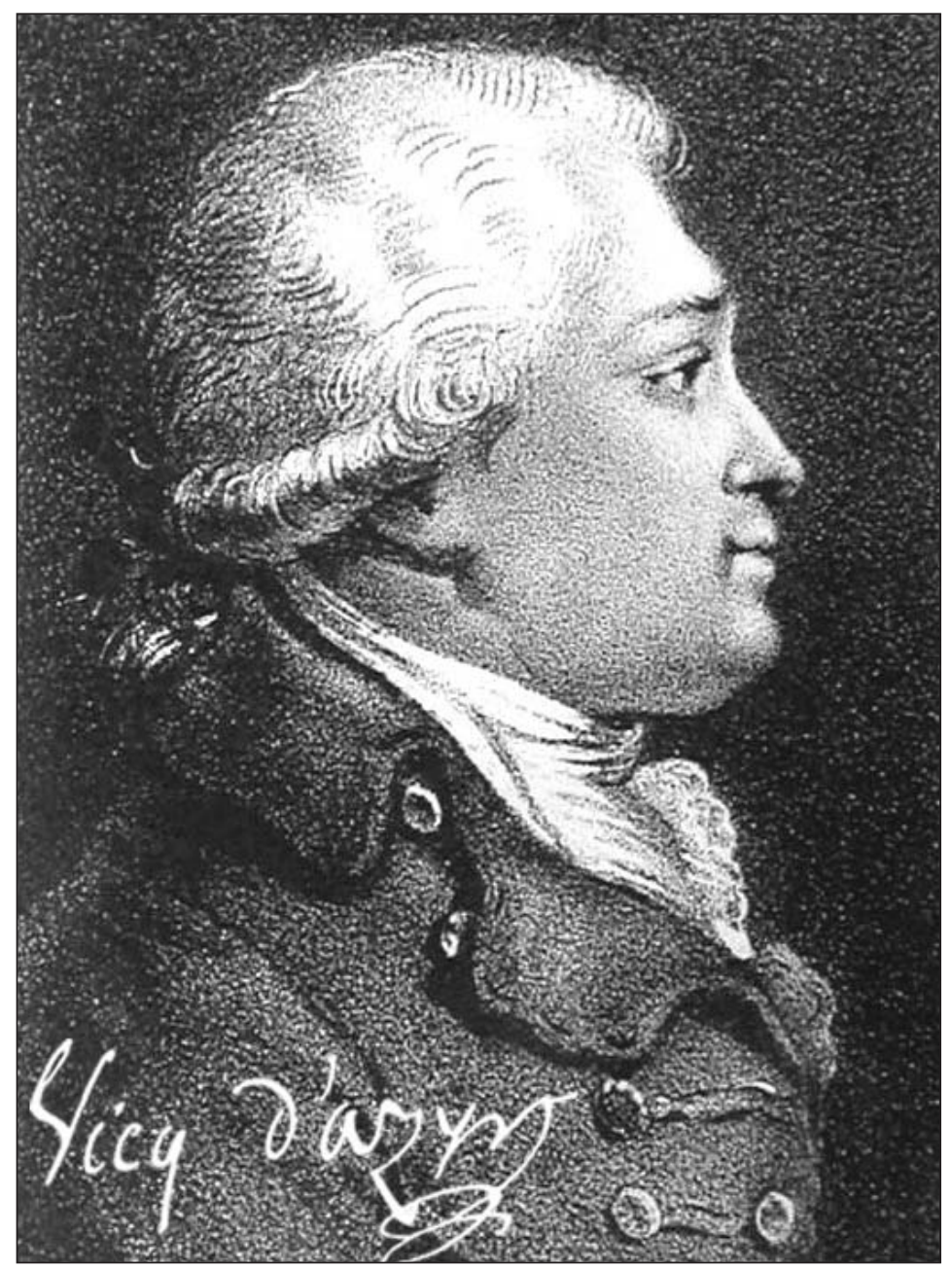

Figure 1: A portrait of Félix Vicq d'Azyr. This engraving made by Souflot based on Carrière's lithography is the only officially recognized representation of Vicq d'Azyr; a courtesy of the Académie Nationale de Médecine, Paris. In the archives of his native town, Vicq d'Azyr is described as an individual with "a handsome figure, elegant and somewhat cold in appearance, but full of dignity, with a noble expression and a soft and affectionate voice. Within him the seriousness of the man of science is tempered by the distinction and manners of a man of high society." Vicq d'Azyr's signature was taken from a handwritten letter found at the Library of the Académie Nationale de Medicine and electronically imported onto the portrait.

thinking about anatomy comparatively. ${ }^{5}$ In 1772 , at age 24 , he passed his license examinations brilliantly and defended a thesis on the intracranial mechanisms protecting the brain in case of concussion that earned him fame in the Parisian medical society. ${ }^{6,7}$ In the summer of 1773 , while still a medical student, Vicq d'Azyr initiated a series of highly successful lectures on human and animal anatomy at the Paris Medical School. However, because of the opposition of various senior medical staffs, he was denied access to the faculty's amphitheater during the fall and had to teach in private facilities on rue de la Pelletrie and later on rue du Sépulcre. Before retiring at Fontenay-auxRoses, Antoine Petit designated Vicq D'Azyr as his successor at the chair of anatomy at the Jardin du Roi, but Buffon (Georges Louis Leclerc, Count of Buffon, 1707-1788), who reigned supreme over this Institution, decided otherwise; he choose the Montpellier-trained anatomist Antoine Portal (1742-1832), who was already professor at the College Royal since 1774. While forced to take some rest in Normandy because of severe hemoptysis due to a pulmonary ailment, Vicq d'Azyr initiated a series of studies on the anatomy of fishes and birds, the results of which worth him a seat at the Royal Academy of Sciences in 1774 at age $26 .^{1-4,6-8}$ This position allowed him to become acquainted with the philosopher and mathematician Condorcet (Jean-Antoine-Nicolas Caritat, marquis de Condorcet, 17431794), who was then Secretary of the Academy of Sciences, and with the first physician to Queen Marie-Antoinette (1754-1793) de Lassone (Joseph-Marie-François de Lassone, 1717-1788).

In the archives of the city of Valognes, Vicq d'Azyr is described as being tall, imposing, with a handsome figure, a noble and open physiognomy, and a voice sweet and sonorous, made to move and to persuade. ${ }^{49}$ His talent is said to have resided in the double faculty of conceiving with grandeur and observing with patience, a combination rare enough, but without which even genius produces nothing complete. ${ }^{4.9}$ Dominated by 

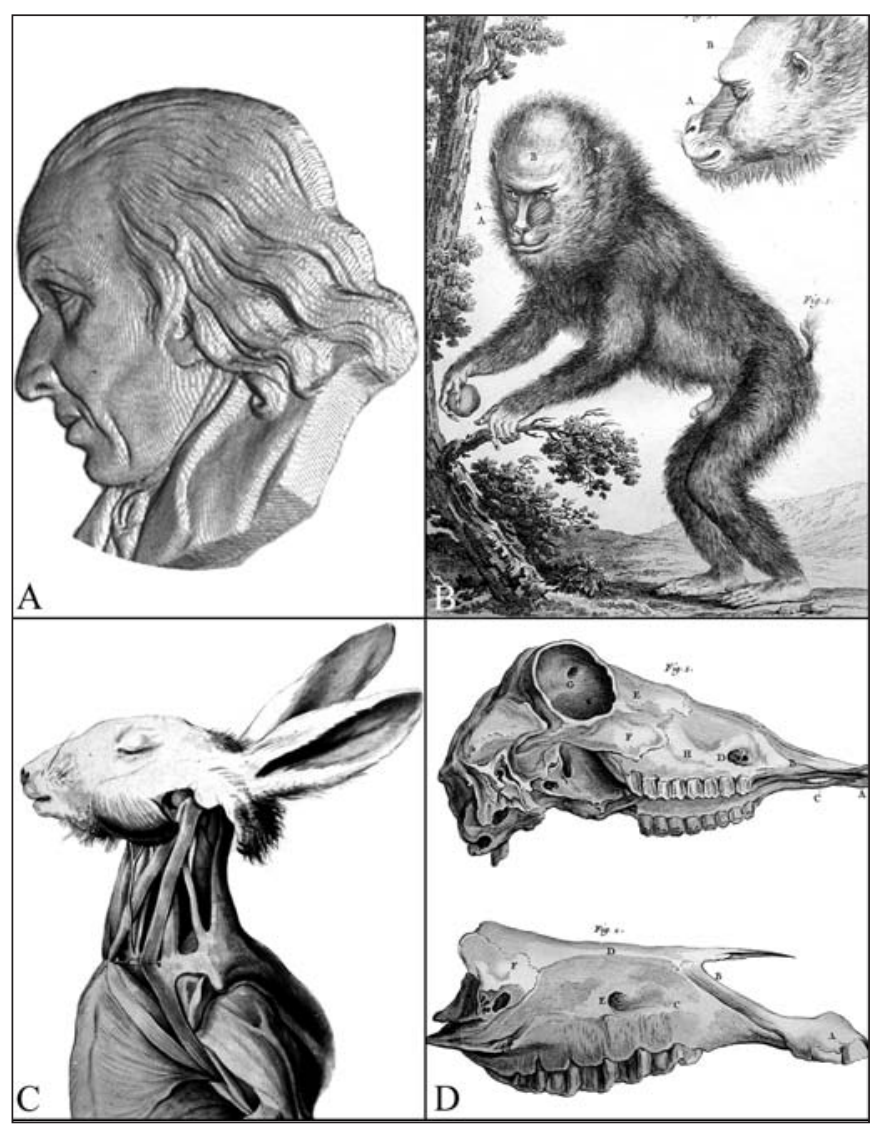

Figure 2: Vicq d'Azyr and comparative anatomy. A: A portrait de Daubenton drawn by Adrien Feart around 1813; a courtesy of the Smithsonian Institution. B: Drawings depicting a standing mandrill and a lateral view of the head of another mandrill. C: A drawing by Alexandre Brisseau made under Vicq d'Azyr's supervision and showing the collarbone of a leveret; a courtesy of the National Museum of Natural History, Paris. D: Drawings showing the skull of a sheep and the anterior maxillary bone of a horse fetus. Figures $B$ and $D$ are from Vicq d'Azyr F. Observations anatomiques sur trois singes. Mémoires de l'Académie Royale des Sciences de Paris, 1780, p. 478-493.

two major ambitions - that of learning and that of gaining recognition - Vicq d'Azyr always knew how to reconcile scientific rigor with the good manners of a man of fashionable society. ${ }^{4,8}$ Vicq d'Azyr married a certain Miss Lenoir, the niece of Daubenton or perhaps of Daubenton's wife, somewhere around 1779 , but the poor lady died most likely of pulmonary ailment only 18 months later. ${ }^{6,10}$ Vicq d'Azyr remained faithful to his beloved wife and never remarried; this event nevertheless allowed him to get even closer to Daubenton.

Vicq d'Azyr became known to the French nobility and general public after his successful management of a severe cattle plague that occurred in the southern part of France in 1774 . He was answering a request made by the omnipotent minister of finance Anne-Robert-Jacques Turgot (1727-1781) to the Academy of Sciences for a physician and a physicist to delimitate the contagious areas: Vicq d'Azyr did both. Inspired by the English physician Thomas Sydenham (1624-1689), who made pioneering studies on epidemics, Vicq d'Azyr successfully managed this epizootic (rinderpest) by having all infected animals slaughtered and buried, by prohibiting animals movement in infected areas and by advocating stringent hygienic measures; all of which are methods similar to those in use today to treat bovine spongiform encephalopathy. ${ }^{11}$ Although fully aware that rinderpest was an infectious disease, Vicq d'Azyr failed in trials of inoculation against the disease, an attractive idea to many of his contemporaries by analogy with smallpox inoculation, and concluded that the only solution was to stamp out infected animals. ${ }^{12}$ Vicq d'Azyr was nevertheless

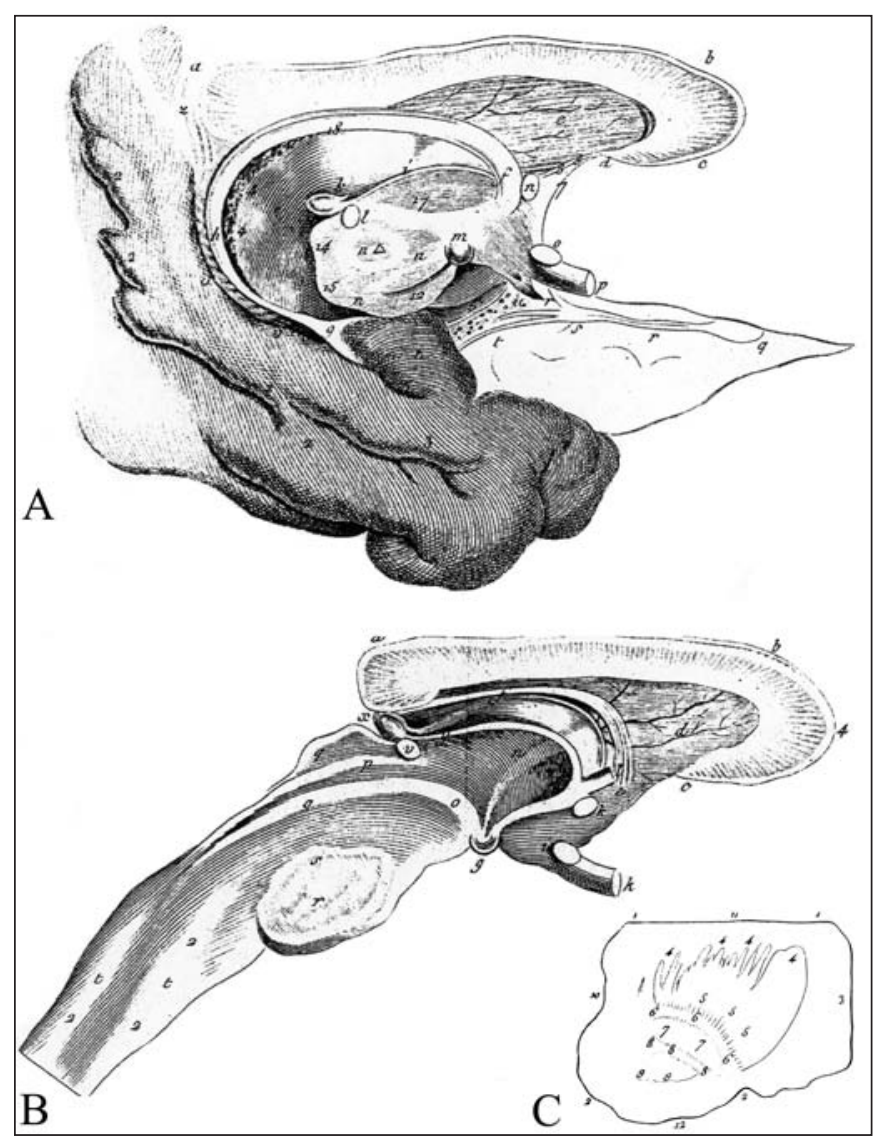

Figure 3: Vicq d'Azyr and human brain anatomy. A: Drawing of a human brain sectioned along the sagittal plane and illustrating, among other things, the corpus callosum, striatum, fornix, pineal gland and stria medullaris. The olfactory bulb, peduncle and stria are also illustrated together with the anterior perforated substance. B: Drawings of a parasagittal section of the human brain depicting many of the structures mentioned above plus the mammillo-thalamic tract. These two figures are from from Vicq d'Azyr F. Recherche sur la structure du cerveau. Mémoires de l'Académie Royale des Sciences de Paris, 1784, p. 495-622. They correspond respectively to Figures 1 and 3 of plate I. C: Drawing showing the striatum and the inner and outer pallidal segments, which are particularly well delineated in this sagittal section. This illustration corresponds to Figure 5 of plate XIV in Vicq d'Azyr F. Traité d'anatomie et de physiologie. Paris: Didot, 1786. 
instrumental in establishing in France a public sanitary structure based on a statistical and epidemiological knowledge of human diseases. ${ }^{13}$ Hence, the young doctor busy practising medicine, teaching anatomy and doing important research in comparative anatomy, rapidly became an expert advisor on the control of epizootics as well as a pioneer in the field of public hygiene and preventive medicine. In so doing, Vicq d'Azyr was following the example of the Italian physician and anatomist Giovanni Maria Lancisi (1654-1720) who did the same in the Papal States in 1711. ${ }^{11,14}$ Interestingly, Lancisi like Vicq d'Azyr saw his name attached to some brain structures, particularly the striae that course along the corpus callosum within the indusium griseum, a remnant of the dorsal hippocampal formation. ${ }^{15}$

When he returned to Paris in 1776, Vicq d'Azyr initiated a series of studies on epidemiology and related public health matters, such as the quality of air and water and the danger of burials within the confines of city centers. Theses investigations led to the publication of several treatises on these important public issues. ${ }^{16,17}$ Realizing that a precise knowledge of human and animal health conditions in the various regions of France was a prerequisite for the development of adequate preventive measures against epizootic and epidemic diseases, he convinced

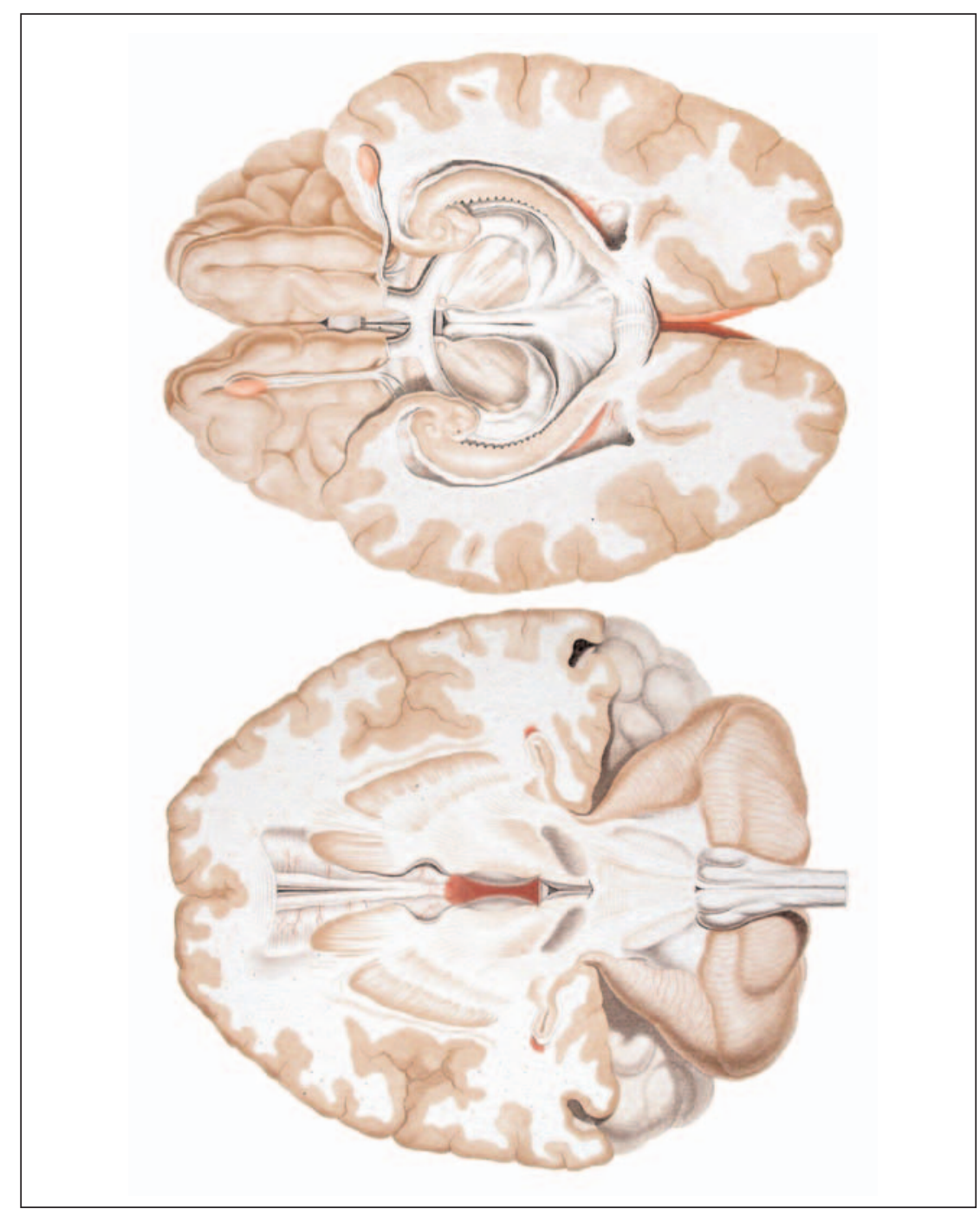

Figure 4: Vicq d'Azyr and his brain anatomy treatise. Reproduction of two color figures from Vicq d'Azyr F. Traité d'anatomie et de physiologie. Paris: Didot, 1786. These figures depict horizontal sections through the human brain taken at two different dorsoventral levels. The upper figure corresponds to treatise's plate XX; it displays a ventral view with parts of the temporal lobe dissected out to show the hippocampal formation, including the uncus and dentate gyrus. The lower figure corresponds to treatise's plate XXII; it depicts the putamen, caudate nucleus, globus pallidus, claustrum and the substantia nigra. All the plates in this treatise were drawn and engraved by Alexandre Briceau, draftsman to the anatomy cabinet of Alfort Royal Veterinary School. They were made with a combination of aquatint, line-engraving, and stipple-engraving and printed in colors. 
the Royal Administration to create a Commission and later a Society for medical correspondence in 1776 to collect such data from physicians and veterinarians throughout the country. In 1778, the correspondence society became the Royal Society of Medicine, with de Lassone as President and Vicq d'Azyr as permanent secretary and moving spirit. ${ }^{3,5}$ Vicq d'Azyr's role as permanent secretary was to take care of a huge correspondence with an extensive network of medical doctors throughout France and abroad, write the historical part of the society's mémoires, and pronounced eulogies of deceased members. Vicq d'Azyr wrote more than 50 eulogies that were models of eloquence and erudition, ${ }^{18}$ as well as a thoughtful and lucid depiction of the historical evolution of scientific ideas. Perhaps one of Vicq d'Azyr's most famous eulogies was the one dedicated to his former friend and colleague Benjamin Franklin (1706-1790) that he pronounced at the Academy on March 1791; its starts with this famous sentence: "A man is dead, and two worlds are in mourning." "This series of masterpieces earned him a seat at the French Academy in 1778, replacing Buffon at the Academy's number one seat. His reception at the French Academy was sumptuous; it was attended by many of his friends, by many famous scientists, including his friend Condorcet, the chemist Antoine-Laurent Lavoisier (1743-1794), the mathemat-ician Jean-Sylvain Bailly (1736-1793), as well as most of the representatives of the Parisian fashionable society, including Prince Henry of Prussia. ${ }^{3,6}$ Hence, while only thirty years old, Vicq d'Azyr was already a member of three of the most prestigious cultural and scientific institutions in France.

Vicq d'Azyr's reputation as physician and anatomist was such that he was invited to contribute to the Encyclopédie Méthodique, a huge cultural and scientific enterprise initiated by the famous Parisian publisher Charles-Joseph Panckoucke (1736-1798) and completed by his daughter Thérèse-Charlotte Agasse. Vicq d'Azyr supervised the team in charge of the medical dictionary in this 200-volume-large encyclopedia, whose publication extended from 1782 to $1832 .{ }^{19}$ Vicq d'Azyr himself contributed several entries, including those on anatomy, hygiene and epidemiology. The physician Moreau de la Sarthe (1771-1826) completed Vicq d'Azyr's encyclopedic work after the premature death of the latter and also published a fairly complete version of Vicq d'Azyr's major works in $1805 .^{2}$

\section{A PIONEER IN COMPARATIVE ANATOMY}

Infatuated with the ideas of Etienne Bonnot de Condillac (1714-1780) and John Locke (1632-1704), Vicq d'Azyr became convinced that the study of man had to be illuminated by the study of animals; for him, the place of man in nature cannot be fully understood unless perceived in relation with the rest of the animal kingdom. ${ }^{10}$ Thanks to Daubenton, he was able to dissect many animals belonging to different genera, including rare specimens gathered from Africa, and he progressively developed a vast knowledge of comparative anatomy (Figure 2B-D). Vicq d'Azyr was the first to enunciate as a biological principle the "correlation of organs." ${ }^{8} \mathrm{He}$ aptly pointed out, for example, that a certain shape of tooth presupposes a certain type of structure in the extremities and the digestive tract, because the animal's bodily parts are adapted to its way of living. This idea was later expanded by the famous naturalist Georges Cuvier (1769-1832), who showed that it was possible to reconstruct extinct animals

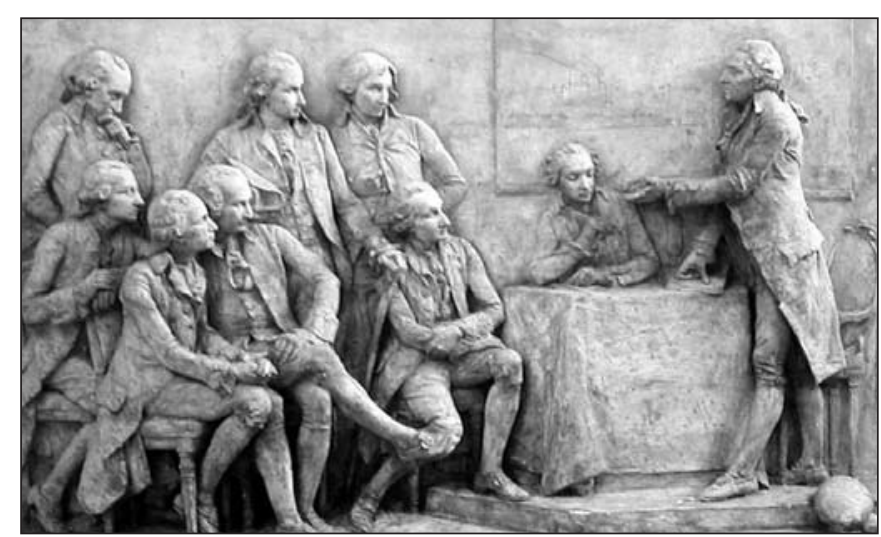

Figure 5: Vicq d'Azyr and the French Revolution. This bas-relief shows Lavoisier explaining the results of his research to some of the major scientific figures of his time, sometime before he was guillotined in 1794 during the Terror. Standing, from left to right: Vicq d'Azyr, Pierre-Simon Laplace (1749-1792, mathematician and astronomer; Jean-Baptiste Lamarck (1744-1829), evolutionary biologist. Sitting, from left to right: Louis-Bernard Guyton de Morveau (1737-1813), chemist and collaborator of Lavoisier and Fourcroy; Gaspard Monge (1746-1818), mathematician; Claude-Louis Bertholet (1748-1822), chemist; JosephLouis Lagrange (1736-1813), mathematician; and Jean-Antoine-Nicolas Caritat, marquis de Condorset (1743-1794), philosopher, mathematician and politician. Courtesy of the Académie Nationale de Médecine, Paris.

from small fossil fragments by a sequence of deductions based on the interdependence of each organic part. ${ }^{8}$ Vicq d'Azyr's detailed study of the upper and lowed limbs of human compared with those of quadrupeds ${ }^{20}$ allowed him to detected the influence of functional adaptation, a principle that was to become the basis of the transformation theory elaborated by Jean-Baptiste Lamarck (1744-1829).

From his first mémoire on the anatomy of fishes and birds in 1773 to his last observations on chick embryonic development and duck's genital organs in 1793, Vicq d'Azyr applied himself relentlessly to enlighten human anatomy through comparisons with that of animals, in line with his unitary view of medicine. ${ }^{13}$ Many of his comparative studies were undertaken between 1780 and 1788, while he held the chair of comparative anatomy at Alfort Veterinary School. ${ }^{21,22}$ There he worked in close collaboration with his former master Daubenton and one of his protégés, the chemist Antoine-François de Fourcroy (17551809); this was a very happy and highly prolific period for Vicq d'Azyr. Many of his efforts at Alfort were devoted to development of a more accurate and encompassing anatomical nomenclature in line with his precept that "not only corresponding regions of the same organ should wear the same name, but these organs should be termed similarly in all animals; if not, the correspondences suggested by our studies cannot be firmly established."23 Vicq d'Azyr also made instructive comparisons between the study of cadavers and that of living beings. He constantly opposed and compared the two main objects of anatomical studies: "The cadaver, a body formerly alive and suddenly lying cold, silent and unresponsive, and the 
living animal subjected to all scientific tortures to gather truths that are so difficult to observe and acknowledge." 23 By applying his knowledge of anatomy to pathogenesis and symptomatology of diseases, he has markedly influenced the course of medical research during the 18th century and played a key role in the foundation of the anatomo-pathologic school. ${ }^{24}$ The following excerpt from his work on the voice organs in different species is particularly revealing of the type of philosophy of nature that Vicq d'Azyr espoused: "Breathing is not only one of the first means whereby life is sustained, it also serves to establish intimate communication between animals. When breathed out, air converts itself into a multitude of sounds; it becomes the primary element of various voices and it brings the different animated beings closer to one another through a language without which nature would seem plunged into an eternal sleep."23 Throughout his scientific career, Vicq d'Azyr pleaded for the development of functional anatomy, an idea that he said to have inherited from the famous Swiss physiologist Albrecht von Haller (1708-1777). For Vicq d'Azyr, anatomy was only the skeleton of science; in order to be useful, anatomy - the science of death - had to be put into movement by physiology - the science of life. ${ }^{23}$

\section{A MAJOR CONTRIBUtion TO BRAIN ANATOMY}

Knowledge of brain anatomy did not progress significantly after the major contribution made by Andreas Vesalius (15141564) during the Renaissance. ${ }^{25}$ French physicians of the 18th century were relying on Jean Riolan (1580-1657) and Raymond Vieussens (1641-1716)'s anatomical treatises, ${ }^{26,27}$ where brain descriptions are buried in chapters devoted to splanchnology, with the dura mater considered as an envelope similar to the pleura and peritoneum that surround thoracic and abdominal viscera. ${ }^{3,8}$ In contrast, Vicq d'Azyr was fascinated by the brain as the organ of thought and felt that the advancement of science would largely benefit from a better knowledge of the functional anatomy of this master organ. Vicq d'Azyr's investigation of the vertebrate brain was initiated in 1777 by a detailed description of the second and third pairs of cervical nerves, which was published in $1779 .{ }^{28} \mathrm{He}$ then presented at the Academy of Sciences in 1781 three copious mémoires on the structure of the brain and the spinal cord and on the origin of the cranial nerves that were published in extenso in 1784 and which contained many novel descriptions. ${ }^{29}$

Vicq d'Azyr's dissections of the human brain were facilitated by a fixation technique that he borrowed from the Dutch anatomist Frederik Ruysch (1638-1731) and which consisted of a combination of alcohol, saltpeter and hydrochloric acid. ${ }^{30}$ His original dissection technique included scraping along the white matter fibers, a method that was to be extensively used later by Franz Joseph Gall (1758-1828) and Caspar Spurzheim (17761832). ${ }^{31}$ Vicq d'Azyr divided the convex surface of the brain into three major regions: frontal, parietal and occipital, corresponding to the anterior, middle and posterior lobes of ancient authors. He was the first to realize that the human cerebral cortex is not the same throughout and by doing so he initiated the most complex of anatomical specialties, the study of the cerebral cortex. ${ }^{9} \mathrm{He}$ isolated the central fissure and the pre- and post-central gyri but did not name them. Ironically, it is the name of the Italian neuroanatomist Luigi Rolando (1773-1831) that became eponemically attached to the central fissure in the midst of the 19th century because of a misreading of Vicq d'Azyr's work by the French neuropsychiatrist François Leuret (1796-1851). 6,8,31 Vicq d'Azyr is also the first to have accurately depicted the mammillo-thalamic tract, which is still named the "bundle of Vicq d'Azyr." This bundle appears to have been discovered by the French physician François Pourfour du Petit (1664-1741) and the Italian anatomist Giovanni Domenico Santorini (16811737). ${ }^{32,33}$ However, Vicq d'Azyr must be given credit for having provided the first detailed description of the course of this bundle through the thalamus, as he did for the fornix and the stria medullaris, which he called the peduncle of the pineal gland (Figure 3A, B). Vicq d'Azyr also provided unsurpassed depictions of the hippocampal formation (Figure 4, upper panel) and identified the occipito-parietal and calcarine fissures, the cingulate gyrus, the precuneus and cuneus, the uncus, the anterior and posterior perforated substances, the insula, the spino-thalamic tract, various cerebellar sulci, the claustrum and the internal structure of the spinal cord. ${ }^{8,9,30,34}$ Furthermore, it is Vicq d'Azyr and not Samuel Thomas Soemmerring (1755-1830), as commonly believed, who discovered and first illustrated the substantia nigra ("j'appelerai cette espace tache noire ou locus niger crurum cerebri”) (Figure 4, lower panel). Vicq d'Azyr also complemented the pioneering description of the basal ganglia (corpus striatum) provided by the English physician and anatomist Thomas Willis (1621-1675) in 1664. ${ }^{35}$ He made a clear distinction between the caudate nucleus and the putamen and noted the existence of the two segments of the globus pallidus (Figure 3C), which were named 50 years later by the German neuroanatomist Karl Friedrich Burdach (1776-1847). Vic d'Azyr also contributed to our knowledge of the function of the brain. For example, he demonstrated experimentally as well as anatomically the existence of the intraventricular foramen by watching the inflation of the lateral ventricles following the injection of air within the third ventricle. ${ }^{29}$ Overall, however, his work on cerebral physiology was much less accurate than his contribution to the structural organization of the brain. For example, Vicq d'Azyr espoused an outmoded medieval view advocated by Galen (fl. c. 129-200 AD) regarding the decussation of the optic nerves; he believed that the optic fibers did not cross the midline, except in some bony fishes where he thought that the decussation was complete. ${ }^{8}$ Moreover, Vicq d'Azyr did not add much to what was already known about neurological diseases; in fact, he commented relatively little on his activities as a physician.

Most of Vicq d'Azyr's findings on human neuroanatomy are summarized in a remarkable treatise on anatomy and physiology that he published in 1786 and dedicated to King Louis XVI $(1754-1793) .{ }^{23}$ It is a large folio volume that contains 35 naturesized, colored, human brain figures of a quality and exactitude never attained before (Figure 4). The color figures are accompanied by line drawings with minutely detailed explanations of the various brain structures identified and a critical history of the figures given on the same subject by preceding anatomists. The core of the work is preceded by a very elegant discourse on anatomy, which philosophically elevates this science to a degree not reached before and which strongly argues for the development of a general nomenclature that could be applied to all species. This book was to be the first of a long 
series of volumes on vertebrate anatomy, but the work came to an abrupt end with the advent of the French Revolution.

\section{VicQ D'Azyr AND THE French REVOLUTION}

Vicq d'Azyr had a profound disdain for sectarianism. He was a typical figure of the Ancien Régime, deeply entrenched into the Enlightenments, entirely devoted to the development of encyclopedic knowledge, and unwilling to accept the extreme views advocated by the leaders of the French Revolution. Vicq d'Azyr's unfailing faith to his personal values placed him in a very difficult position for the years to come.

In 1789, after the death of de Lassone, Vicq d'Azyr was appointed physician to Queen Marie-Antoinette. During the summer of the same year, Vicq d'Azyr became acquainted with Governor Morris (1752-1816), the plenipotentiary minister of the United States of America in France, and he is believed to have transmitted letters and missives from the King and the Queen of France to London via Morris. ${ }^{36}$ Vicq d'Azyr greatly admired Marie-Antoinette, who called him "my philosopher," and this rendered Vicq d'Azyr even more suspicious to the revolutionaries.

In 1790, Vicq d'Azyr presented to the Constituent Assembly a lucid and decisive plan to reform the teaching of medicine in France. The document opens up on a severe denunciation of the current medical teaching, which Vicq d'Azyr considered perverted and worthless ("partout viscieux et nul"). The plan itself called for the grouping of medicine, surgery, veterinary and pharmacy schools into a single teaching entity, the establishment of a close tie between the hospitals and the Faculty of medicine, the nomination of faculty staffs through objective competitions (concours), the active participation of students in clinical work and the sanction of medical training by competitive examinations. ${ }^{37}$ Unfortunately, Maximilien Robespierre (17581794), Georges Danton (1759-1794) and their co-disciples had other preoccupations at that time and did not pay much attention to the document. Furthermore, a motion put forward to the Constituent Assembly on August 1793 by the painter JacquesLouis David (1748-1825) led to the abolition of the Royal Society of Medicine and all other scientific and cultural bodies, including medical schools. Vicq d'Azyr's plan nevertheless managed to survive the turmoil of the French Revolution and was progressively implanted in France during the postrevolutionary period, thanks to Fourcroy's efforts. This visionary plan entirely reformed the way medicine was taught in France in the 19th and 20th centuries and it is still the basis upon which academic medicine is organized today in several European countries.

Suspected of intelligence with the "enemy" by the revolutionaries, Vicq d'Azyr's situation was getting more and more precarious. In 1794, Fourcroy, who owned so much to Vicq d'Azyr, saved the situation, at least for a while, by having him named Head of the Saltpeter Commission, the role of which was to rake up each Parisian quarter in search of this compound that enters into the fabrication of gun powder. As Head of this Commission, Vicq d'Azyr was forced to participate in the Supreme-Being celebration organized by Robespierre on June 8, 1794 , and this worsened his already fragile health condition. As a result, Vicq d'Azyr was bedridden in the apartment he occupied, as permanent secretary of the Royal Society of
Medicine, in the National Museum Building, which was then part of the Louvre complex. Suffering from high fever, he experienced horrible nightmares in which he saw many of his closest friends, including Lavoisier, Bailly and Condorcet (Figure 5), crying for help from the guillotine. Vicq d'Azyr died in a state of permanent terror on June 20, 1794 at age 46. Fear, tuberculosis, aneurysm or even suicide; the exact cause of Vicq d'Azyr's death still escapes us. ${ }^{1-4,6,8,10,13,24}$ In any event, the sad condition of his disappearance did not diminish the impact of his major contribution to the field of medicine and anatomy. Thirty years of hard work made Vicq d'Azyr one of the most representative figures of the French medical world during the Age of the Enlightenment.

\section{ACKNOWLEDGEMENTS}

The author thanks Dr. Martin Parent, Département de pathologie et de biologie cellulaire, Université de Montréal, for his precious help with the illustrations. Thanks also to Mrs. Marie Davaine for having given me access to library of the Académie Nationale de Médecine, Paris.

\section{REFERENCES}

1. Lafisse C. Éloge de Vicq d'Azyr lu à la deuxième séance publique de la Société de médecine, le 12 novembre 1797. Paris: Imprimerie de la Société; 1797.

2. Moreau (de la Sarthe) JL. Euvres de Vicq d'Azyr, recueillis et publiés avec des notes et un discours sur sa vie et ses ouvrages, ornés d'un volume de planches, grand in-4.0, et d'un frontispice allégorique (6 volumes and an atlas). Paris: Duprat-Duberger; 1805.

3. Cabanis PJG. Éloge de Vicq d'Azyr. In: Euvres complète de Cabanis, vol. V. Paris: Bossanges frères, 1825. p. 179-216.

4. Lémontey PE. Éloge historique de Vicq d'Azyr prononcé dans la séance publique du 25 août 1825. In: Recueil de l'Académie Française, 1820-1829. p. 943-968.

5. Hannaway C. Vicq d'Azyr, anatomy and a vision of medicine. Clio Med. 1994; 25: 280-95.

6. Delbos D. Un médecin Normand à Paris. Thèse de médecine, Caen; 1978.

7. Noir J. Un savant - un innovateur - un réalisateur : Félix Vicq d'Azyr (1748-1794). La Montagne Sainte-Geneviève et ses Abords. Comité d'études historiques, archéologiques et artistiques des Ve et XIIIe arrondissements, 1932; Tome VII: 4863.

8. Leduc B. La vie et l'œuvre anatomique de Félix Vicq d'Azyr. Thèse de médecine. Rennes; 1949.

9. Spillman R. Félix Vicq d'Azyr and Benjamin Franklin. J Neur Ment Dis. 1941; 94:428-44.

10. Peumery JJ. Vicq d'Azyr et la Révolution française. Hist Sci Méd. 2001; 35:263-70.

11. Glynn A, Glynn N. Plus ca change...From rinderpest to bovine spongiform encephalopathy. J R Coll Physicians Lond. 1999; 33:576-80.

12. Meynell E. Vicq d'Azyr and a cattle plague. J R Soc Med. 1998; 91:105-6.

13. Thillaud P. Félix Vicq d'Azyr (1748-1794). Anatomie d'une élection. Hist Sci Méd. 1986; 20:229-36.

14. Lancisi GM. Dissertatio de nativis, deque adventitiis romani coeli qualitatibus, cui accedit historia epidemiae rheumaticae, quae per hyemem Anni MDCCIX vagata est. Roma: F. Gonzaga; 1711.

15. Parent A. Carpenter's human neuroanatomy. 9th ed. Baltimore: Williams \& Wilkins; 1996.

16. Vicq d'Azyr F. Exposé des moyens curatifs et préservatifs qui peuvent être employés contre les maladies pestilentielles des bêtes à corne. Paris: Mérigot l'aîné; 1776. 
17. Vicq d'Azyr F. Essai sur les lieux et les dangers des sépultures. Paris: Didot; 1778.

18. Sainte-Beuve GA. Vicq d'Azyr. In: Causeries du lundi, vol 10. Paris: Garnier frères; 1855. p. 279-311.

19. Vicq d'Azyr F. Dictionnaire de médecine de l'Encyclopédie Méthodique [par une société de médecine, mis en ordre et pubié par M. Vicq d'Azyr et continué par M. Moreau de la Sarthe]. Paris: Panckoucke et Vve Agasse; 1787-1830.

20. Vicq d'Azyr F. Mémoire sur les rapports qui se trouvent entre les usages et la structure des quatre extrémités dans l'homme et dans les quadrupèdes. Mémoires de l'Académie Royale des Sciences de Paris-Année 1774. Paris: Imprimerie Royale; 1779. p. 250-70.

21. Vicq d'Azyr F. Observations anatomiques sur trois singes appelés le Mandrill, le Callitriche, \& le Macaque, suivies de quelques réflexions sur plusieurs points d'anatomie comparée. Mémoires de l'Académie Royale des Sciences de Paris - Année 1780. Paris: Imprimerie Royale; 1784. p. 478-93.

22. Vicq d'Azyr F. De la structure des organes qui servent à la formation de la voix considérée dans l'homme et dans les différentes classes d'animaux et comparés entre eux. Mémoires de l'Académie Royale des Sciences de Paris - Année 1779, Paris: Imprimerie Royale; 1782. p. 178-206.

23. Vicq d'Azyr F. Traité d'anatomie et de physiologie avec des planches coloriées représentant au naturel les divers organes de l'homme et des animaux. Paris: Didot; 1786.

24. Dufresne AJLM. Notes sur la vie et les œuvres de Vicq d'Azyr (1748-1794). Histoire de la fondation de l'Académie de Médecine. Thèse de médecine, Bordeaux, 1906.

25. Vesalius A. De humani corporis fabrica, libre septem. Basle: Johann Oporinus; 1543.

26. Rilolan J. Anthropographia et osteologia. Paris: Denys Moreau; 1626.
27. Vieussens R. Neurographia universalis. Lugduni: Jean Certe; 1684.

28. Vicq d'Azyr F. Mémoire sur la description des nerfs de la seconde et troisième paire cervicale. Mémoires de l'Académie Royale des Sciences de Paris - Année 1777. Paris: Imprimerie Royale; 1779. p. 21-40.

29. Vicq d'Azyr F. Recherche sur la structure du cerveau, du cervelet, de la moelle allongée, de la moelle épinière ; \& sur l'origine des nerfs de l'homme \& des animaux. Histoire de l'Académie Royale des Sciences de Paris - Année 1781, Paris: Imprimerie Royale; 1784. p. 495-622.

30. Farrell PS, McHenry LC Jr. Fragments of neurologic history: Félix Vicq d'Azyr and neuroanatomy. Neurology. 1987; 37:1349-50.

31. Boling W, Olivier A, Civit T. The French contribution to the discovery of the central area. Neurochirurgie. 1999; 45: 208-13.

32. Meyer A. Historical aspects of cerebral anatomy. London: Oxford University Press; 1971.

33. Goldblatt D. The key to the brain. Félix Vicq d'Azyr (1748-1794). Semin Neurol. 1986; 6:231-7.

34. Dubois F. Recherches hsitoriques sur les dernières années de Louis et de Vicq d'Azyr. Bull Acad Natle Méd. 1866; 32:9-57.

35. Willis T. Cerebri anatome: cui accessit nervorum descriptio et usus. Londini: typ. J. Flesher, imp. J. Martyn \& J. Allestry; 1664.

36. Morris G. The diary and letters of Gouverneur Morris. Anne Cary Morris, editor, 2 vols. New York: C. Scribner's sons; 1888.

37. Vicq d'Azyr F. Nourveau plan de constitution pour la médecine en France présenté à l'Assemblée Nationale par la Société Royale de Médecine, s.l., 1790. p. 201. 